\title{
INVESTMENT MANAGER'S RESPONSIBILITY RELATED TO THE DEFAULT TOWARDS THE INVESTOR
}

\author{
Dea Justicia Ardha ${ }^{1}$
}

\begin{abstract}
Mutual funds are a forum for fund owners/investors to invest their funds in securities portfolios by the Investment Manager, in other words, the investment manager has an important role in managing investors' funds. Moreover, the funds managed by the investment manager are very large, however, the regulation regarding this matter is deemed inadequate so it is not uncommon for investment managers to neglect by ignoring the rights of investors which cause investors to suffer losses and are not protected. The issues that will be discussed are how the legal protection provided to mutual fund investors and the responsibilities of investment managers who default on losses suffered by investors. Based on these issues, the purpose of this research is to find out the legal protection for mutual fund investors who suffer losses due to errors from investment managers. This research uses an empirical legal research method by using the data collection techniques through interviews. From the data obtained, it shows a form of protection that given provided to investors is in the form of opened information. The investment manager will be responsible for the losses suffered by the investors, but is not more than the fee given by investors to the investment manager. If the investors' report is not responded to, or Bapepam's action against the investment manager which is proven to be inadequate for investors, then investors can file a lawsuit against the law through the district court. Investors must have sufficient evidences to prove the investment manager's negligence which resulted in losses.
\end{abstract}

Keywords : Responsibility, Default, Investor.

\section{The Introduction}

In the explanation of Law Number 8 of 1995 concerning the Capital Market, it is stated that the objective of the capital market is to support the implementation of national development in the context of increasing equitable growth and national economic stability towards improving the people's welfare. In order to achieve this goal, the capital market has a strategic role as a source of financing for the business world, including medium and small enterprises for business development, while on the other hand the capital market is also a vehicle for investment for the community, including small and medium-sized investors.

This is in accordance with the basic objectives of sustainable development, namely increasing economic growth and equitable distribution of income to develop a globally oriented economy in accordance with advances in science and technology for the people's welfare.

As an investment vehicle for investors to support this role, the capital market needs to be supported by the following elements: Adequate infrastructure, which is equipped with elements of supervision (market

Fakultas Hukum Universitas Muhammadiyah Palembang, Email:
deajusticia14@gmail.com 
surveillance), self regulatory organization (SRO), clearing, settlement and proper storage; A strong legal framework, if it already has a good legal basis in the form of laws and implementing regulations that regulate all aspects of capital market activities itself and increasingly trustworthy law enforcement; and professional attitude of capital market players, who have the necessary technical skills and uphold their respective professional ethics. (Nasarudin \& Surya, 2007: 32).

The role of the three supporting elements will create an orderly, fair and efficient trading system, which in turn will result in market confidence and efficiency in the capital market itself. All of this will end in one final goal, they are the creation of an Indonesian capital market that is competitive, safe, and attractive in winning the competition in the capital market (Nasarudin \& Surya, 2007:33).

The capital market in Indonesia is still relatively new, as is generally the case with capital markets in developing countries, especially when it compared to capital markets in developed countries, the number of Indonesian domestic investors is still relatively small. The Indonesian people don't know the benefits of investing in the capital market, even though the capital market should be the main alternative for investment.

I Putu Gede Ary Suta stated, that one of the indicators to measure the level of progress of a country's capital market lies in the level of variation in available investment instruments. The more advanced the capital market is, the more varied the capital market instruments are and the more varied the market instruments are traded on the stock exchange. The more instruments offered will make more choices for market players and the possibility that the market will be increasingly attractive to the investors, both local and foreign (Suta, 2000: 255).

The capital market will bridge the relationship between fund owners or investors with those who will use the funds or issuers (companies). Investors will use the instrument for the purposes of their portfolio in order to maximize the instrument's point income. The capital market is divided into two major groups, they are ownership instruments such as stocks and debt instruments such as bonds (contract). Besides of stocks and bonds (contract), the capital market also has other instruments such as mutual funds, credit securities and warrants.

The capital market doesn't stand alone, but is carried out by various parties involved in capital market activities, including: Capital market authority is a capital market supervisory agency - financial institution (hereinafter referred to as (BAPEPAM-LK) which is under the auspices of the Ministry of Finance / Minister of Finance; Stock Exchange; Issuer; Securities stocks consisting of securities issuance loan underwriters (PEE), brokers or securities brokers (PEE), and investment managers (MI); Clearing guarantee and guarantee institutions (LKP); Depository and settlement institutions (LPP); Capital market supporting institutions (LPPM), consisting of the Trustee Custodian and the Securities Administration Bureau (BAE); Capital market supporting profession (PPPM), including public accountants, legal consultants, notaries and appraisal companies; Investors, which consist of individual or individual investors and institutional or institutional investors (Widjaja, 2006: 2). 
Investments in the capital market can be done in several ways, one of which can be done through portfolio investment by buying instruments in the capital market. In this case the investor has no interest in running the business of the company where he invests in the form of shares or resignation, besides the portfolio investment there is also direct investment to investors involved in the establishment of a company. In this case, the investor who has an interest in controlling and running his investment business directly.

Mutual funds are a place that is used to raise funds from the investor community to be invested in the Securities Portfolio by the Investment Manager." It is as a product from investment company.

Mutual funds were first recognized in Belgium in 1822 in the form of closed mutual funds (closed and fund). This mutual fund was created for wealthy investors who want to participate in government debt portfolios who want to have high profit. (Fuady, 1996:106). In 1860 mutual funds began to spread in England and Scotland in the form of unit investment trusts and in 1920 began to be known in the United States as mutual fund (Purba, 2003:8).

As a type of securities in mutual fund investing, it has unique characteristics when compared to other types of investment in mutual funds, investors buy statements on collections of securities that are managed by expert investment managers with the aim of making profits. Investors' funds are used by investment managers to manage their securities investment portfolios to earn profits, then distributed back to investors. However, investment managers who are given the authority to manage funds can only reinvest these funds in the form of a securities portfolio that has been agreed previously and permitted by BAPEPAM -LK. So, here the investment manager is a security manager, who buys and sells securities issued by other companies for the benefit of investors.

An investment manager is the party that manages securities portfolios for customers or manages collective investment portfolios for a group of customers, except for the pension fund insurance companies and banks which carry out their own business activities based on the prevailing laws and regulations. An investment manager is a part of a securities company activity that can be carried out separately or in conjunction with other activities, such as underwriting and brokerage. The role of an investment manager is very important in managing mutual funds in the capital market and is a company that provides services for managing customers' securities portfolios with rewards that calculated based on a certain percentage of the value they manage.

In the Article 27 Paragraph 1 of Law of the Capital Market states about the investment manager's fiduciary duty, which is an obligation in a good faith and full of responsibility to carry out the best possible duties solely for the benefit of mutual funds. Investment manager as a manager of investment portfolios of investors expected to work as well as possible according to the regulations contained in the capital market laws and the regulations from BAPEPAM-LK to avoid fraud committed by investment managers that will harm investors.

Therefore, the main topic of this article What is the civil accountability of mutual fund investment managers as investment managers 
who have harmed their investors and What efforts can mutual fund investors make against investment managers that have harmed them.

\section{Research methods}

The methods used to collect the data needed in this article is to use the doctrinal-nomological method which is based on the doctrinal rules that govern behaviour. The type of research used is normative analysis because it refers to the concept of law as a rule. Research materials that have been obtained, both primary and secondary materials, are analyzed qualitatively, which the collected materials are processed, qualified, and systematically linked to obtain a conclusion in the answer to the problem of civil responsibility of mutual funds investment manager to investors who are harmed in mutual funds, and the efforts that can be made by mutual funds investors against investment manager who has harmed them. The technique of drawing conclusions in this study is inductive, the process of drawing general conclusions or the basis of knowledge about specific things.

\section{Discussion and Results}

\section{Mutual Fund Investment Manager's Civil Accountability Against Investors Who Loss in a Mutual Fund}

Accountability is the obligation to bear everything if anything happens, it can be sued, blamed, and brought up against. In the dictionary of law, responsibility or is an obligation for someone to carry out what has been obliged to him. According to the law, responsibility is an effect of the consequences of a person's freedom regarding his actions related to ethics or morals in carrying out an act. Civil is to regulate legal relations privately or in other words emphasize legal protection for the benefit of individuals or legal entities. Investment Manager is a party whose business activities are managing securities portfolios for customers or managing collective investment portfolios for a group of customers, except for insurance companies, pension funds and banks which carry out their own business activities based on applicable laws and regulations. Investors are individuals or institutions, both domestic and non-domestic, who carry out an investment, both long and short term. So that the investment manager's civil responsibility to an injured investor can be interpreted as the responsibility of an investment manager who has made a mistake that is harmful to his investors.

Every form of investment cannot be separated from the risks. The greater the promise of profit, the greater the risk they get. To minimize the risk of loss, as much as possible, investors and parties carrying out investments must regulate and understand their respective rights and obligations. For investment in mutual fund instruments, potential investors must read and understand the prospectuses held by the company that manages the mutual fund. Accountability that may be requested from the investment manager can be accountability administratively, civilly and criminally. For civil liability, investors can ask the investment manager to take responsibility to compensate for any losses they have suffered due to the default or illegal actions by investment manager (Pariela: 2017). 
The prospectus usually describes the risks involved in investing in mutual funds. The contents of the prospectus must refer to Bapepam Regulation No. IX.C.6-Keputusan Ketua Bapepam No.Kep22/PM/2004 concerning Guidelines and Contents of a Prospectus for Public Offering of Mutual Funds. Mutual fund risk is also regulated in letter $\mathrm{k}$ point (1) of Regulation No.IX.C.6. it is stated that the risk accepted by investors is the decrease in the value of thee share or Participation Unit caused by macroeconomic and security conditions, defaults from parties related to the Mutual Funds, such as banks, other companies issue money market instruments and/or bonds, and change in the value of money market instruments as a result of significant movements in interest rates and currency exchange rates. According to Roeslan Saleh on Criminal Liability:

"Criminal responsibility is defined as the continuation of objective reproaches that exist in criminal acts and subjectively fulfill the requirements to be convicted for their actions." (Saleh, 1983: 20-23).

The purpose of objective reproach is that the act committed by a person is indeed an act that is prohibited. The indicator is that the act is against the law, both in the sense of being against the formal law and against the material law. While the purpose of subjective reproach refers to the person who commits the prohibited act. Even though the prohibited act has been carried out by a person, but if that person cannot be reproached because there is no mistake in him, then the criminal responsibility cannot exist (Abidin, 1987: 72). An act can be said to have violated the law, and can be subject to criminal sanctions, it must fulfill two elements, they are the presence of elements of a criminal act which in the foreign language is actrus reus and the state of the inner nature of the maker which in the foreign language is mens rea. Error or schuld is an element of the maker of the offense, so it includes an element of criminal responsibility which contains the meaning that the maker can be blamed for his actions. In the event that the guilt is not proven, it means that the criminal act is not actually proven, because it is impossible for the judge to prove a mistake if he has known beforehand that the criminal act did not exist or was not proven to have been realized by the defendant (Amrani \& Ali, 2015: 21).

According to Moeljatno (in Tri Andrisman) the elements of criminal responsibility are:

a. Mistake;

b. Responsible ability; and

c. There is no excuse (Amrani \& Ali, 2015: 30).

Based on the explanation above, it can be seen that the subject of criminal responsibility who will be responsible for a criminal act is the perpetrator of the crime, in this case a human or a corporation. Therefore, the subject must be the same between the perpetrators of the crime and those who will be responsible for their criminal acts.

According to the view of Ey. Kanter and SR. Sianturi, who are considered as subjects of criminal acts are humans (natuurlijke-personen), while animals and legal entities (rechtspersonen) are not considered as subjects. (catatan kaki 13) That only humans are considered the subject of criminal acts, this is concluded, among others, from:

a. In the formulation of the offense in determining the subject of the crime there are terms: whoever, Indonesian citizen, captain, civil 
servant, and so on. These terms, apart from those specified in the formulation of the offense concerned, are found to be based on articles: 2 to 9 of the Criminal Law Code. For the term whoever, in articles 2, 3 and 4 of the Criminal Law Code the term een ieder (everyone) is used;

b. In the provisions regarding criminal acts as regulated in Article 10 of the Criminal Law Code, especially regarding fines, only humans have the mind to understand the value of money; and

c. In the provisions regarding criminal liability as regulated in Articles: 44, 45, 49 of the Criminal Law Code, which implies as from the act (geestelijke vermogens) (Gribaldi: 2013).

From the description of the explanation above, it can be seen that the object of criminal responsibility as described above is a criminal act committed, objectively the person has committed a crime or violation in accordance with the conditions determined by law, thus the principle of legality becomes a benchmark seen subjectively, the person or actor already has the capacity to be held accountable where the benchmark is an error

In the provisions of Law Number 8 of 1995 there are only 2 (two) articles that specifically regulate investment responsibilities, they are:

Article 27

1) The investment manager is obliged in good faith and responsibly to carry out good duties, perhaps solely for the benefit of mutual funds;

2) If the investment manager does not carry out his obligations as referred to in paragraph (1) the investment manager shall be responsible for all losses arising from his actions (Gribaldi: 2013: 347352 ).

To determine whether there is an element of error or negligence of the investment manager that results in investor losses, of course, it cannot be done unilaterally. Supervision of all activities related to the issuance of mutual funds falls under the domain of the Capital Market Supervisory Agency (Bapepam). One of the powers of Bapepam, pursuant to Article 5 letter (e) of Law Number 8 of 1995 concerning the Capital Market, is to conduct examinations and investigations against each Party in the event of an event suspected of being a violation of this Law and or its implementing regulations. Based on these provisions, investors who feel that the investment manager has made negligence that results in losses can complain to Bapepam.

\section{A Lawsuit from the Injured Party as a Result of the Mutual Fund Investment Manager's Actions.}

Investors are those who suffer losses due to the investment manager's actions. Investors can file a lawsuit based on Article 61 of Law Number 40 of 2007 concerning Limited Companies if they feel their rights have been violated by the opened investment manager with the occurrence of bankruptcy. In addition to this article, there is also Article 97 Paragraph (6) of Law Number 40 of 2007 concerning Limited Companies which regulates about granting rights to investors to sue members of the board of directors if there is an error by a member of the board of directors in running the company, a director carries out the management that entrusted to him. 
In addition to the articles mentioned above, there is also article that gives investors the right as shareholders to demand a buyback of their shares; it is in Article 62 of Law Number 40 of 2007 on Limited Companies, which reads:

Each shareholder has the right to request the company to approve the company's actions that are harmful to the company:

a. Amendments to the articles of association.

b. Multiplication or guaranteeing company assets that have a value of more than $50 \%$ of the company's net assets.

c. Merger, consolidation, acquisition or separation.

Based on this article, investors as shareholders can demand an obligation to buy back their shares from the process of purchase on the capital market. If the research managed by the Financial Services Authority proves that there is an investor's loss caused by the actions of the issuer, the Financial Services Authority can file a civil suit on behalf of the investor in accordance to Article 30 of Law Number 21 of 2011 concerning the Financial Services Authority:

1) For the protection of consumers and the public, the Financial Services Authority has the authority to provide legal defense, includes:

a. To rule or to take certain actions to financial service institutions to resolve consumer complaints that have been disadvantaged by financial service institutions.

b. File a lawsuit:

1. To take the assets back belongs to the party that has suffered losses from the exploiting party who caused the loss or under the control of another party in good faith.

2. To receive compensation from parties that cause harm to consumers or financial service institutions for the laws and regulations in the financial services sector.

2) Compensation as referred to in paragraph (1) letter b number 2 is only used to pay compensation for the losses to the injured party.

\section{Conclusion}

Based on the problems studied about Investment Manager Civil Accountability against Investors who suffer losses in Mutual Funds that the investment manager's responsibility towards the investor who is injured in the mutual fund is that if it is proven that they have committed an act prohibited in the agreement, so that the investment manager is having responsible for the losses that received by investors due to violations committed by the investment manager. 


\section{References}

Abidin, Andi Zainal. (1987). Asas-asas hukum pidana bagian pertama, Alumni.

Amrani, Hanafi \& Ali, Mahrus. (2015). Sistem pertanggungjawaban pidana perkembangan dan penerapan, (1th ed.). Rajawali Pers.

Fuady, Munir. (1996). Pasar modal modern. PT Citra Aditya Bakti.

Gribaldi, Muhammad. (2013). Analisis yuridis pertanggungjawaban pidana terhadap pelaku tindak pidana perikanan (Studi Putusan Nomor:237/PID.SUS/2013/PN.TK). Diligib Unila, URL : http://digilib.unila.ac.id/532/1/COVER\%20DALAM.pdf

Nasarudin, M Irsan \& Surya, Indra. (2007). Aspek hukum pasar modal Indonesia (4th ed.). Kencana.

Pariela , Marselo Valentino Geovani. (2017). Wanprestasi manajer investasi terhadap investor reksadana, SASI , 23(2), 129-135. $10.47268 /$ sasi.v23i2.100.

Purba, Victor. (2003). Perkembangan dan struktur pasar modal Indonesia menuju era AFTA. Badan Penerbit Fakultas Hukum Universitas Indonesia.

Suta, I Putu Gede Ary. (2000). Menuju pasar modal modern. 2000. Yayasan Sad Satria Bhakti.

Saleh, Roeslan. (1983). Perbuatan pidana dan pertanggungjawaban pidana; Dua pengertian dasar dalam hukum pidana (3th ed.). Aksara Baru.

Widjaja, Gunawan. (2006). Reksa dana dan peran serta tanggung jawab manajer investasi dalam pasar modal. Prenada Media Group. 